\title{
PARTISIPASI MASYARAKAT PADA PROGRAM PEMBANGUNAN BERBASIS LINGKUNGAN - MEMBANGUN PRASARANA LINGKUNGAN DAN SOSIAL (PBL MAPALUS)
}

\author{
Christiviany Gracanti Tatuh \\ Esry O. H. Laoh \\ Gene H. M. Kapantow
}

\begin{abstract}
ABSRACT
This study aims to identify the shape and level of community participation in the planning, implementation, and supervision of Environmental Based Programs - Building Environmental and Social Infrastructure (PBL-Mapalus). The data used in conducting this research are primary data and secondary data. Primary data is data obtained directly in the field, through interviews and observations using questionnaires / questionnaires. Secondary data is data obtained from related institutions such as the Community Empowerment and Manpower Board of Manado City, Office of Lurah Bumi Nyiur and Tuminting Urban Village Office. Sampling technique in this research used Purposive Sampling. This method is done by taking the people who are selected by researchers according to the specific characteristics possessed by the sample. The result of this research can be concluded that community participation in Environment Based Development Program - Building Environmental and Social Infrastructure (PBL-Mapalus) shows the activity of society is big enough. Although there are still a handful of people who do not know about Environmental-Based Development - Building Environmental and Social Infrastructure (PBL-Mapalus) so it is advisable to the relevant agencies to provide more socialization to the community.
\end{abstract}

Keywords: Form, Level, Community Participation, PBL Mapalus, Tuminting Sub-district, Wanea Sub-district, Manado City

\begin{abstract}
ABSTRAK
Penelitian ini bertujuan untuk mengidentifikasi bentuk dan tingkat partisipasi masyarakat dalam tahap perencanaan, pelaksanaan, pengawasan Program Berbasis Lingkungan - Membangun Prasarana Lingkungan dan Sosial (PBL-Mapalus). Data yang digunakan di dalam melaksanakan penelitian ini yaitu data primer dan data sekunder. Data primer merupakan data yang didapat langsung di lapangan, melalui wawancara dan observasi dengan menggunakan daftar pertanyaan/kuesioner. Data sekunder merupakan data yang diperoleh dari instansi terkait seperti Badan Pemeberdayaan Masyarakat dan Pemerintahan Kelurahan Kota Manado, Kantor Lurah Bumi Nyiur dan Kantor Lurah Tuminting. Teknik pengambilan sampel atau teknik sampel yang digunakan dalam penelitian ini adalah Purposive Sampling. Metode ini dilakukan dengan mengambil orang-orang yang terpilih betul oleh peneliti menurut ciri-ciri spesifik yang dimiliki oleh sampel itu. Hasil penelitian dapat disimpulkan bahwa partisipasi masyarakat dalam program Pembangunan Berbasis Lingkungan - Membangun Prasarana Lingkungan dan sosial (PBL-Mapalus) menunjukan keaktifan masyarakat cukup besar. Walaupun masih ada anggota masyarakat yang tidak mengetahui tentang Pembangunan Berbasis Lingkungan - Membangun Prasarana Lingkungan dan sosial (PBL-Mapalus) sehingga disarankan kepada instansi terkait untuk lebih banyak memberikan sosialisasi kepada masyarakat.
\end{abstract}

Kata kunci: Bentuk, Tingkat, Partisipasi Masyarakat, PBL Mapalus, Kecamatan Tuminting, Kecamatan Wanea, Kota Manado 


\section{PENDAHULUAN}

\section{Latar Belakang}

Orientasi pembangunan di Indonesia yang masih terfokus pada pertumbuhan ekonomi menyebabkan ketergantungan masyarakat terhadap kebijakan-kebijakan pembangunan pemerintah masih kuat dirasakan. Sehingga peran serta masyarakat dalam aktivitas pembangunan tidak terlihat. Ukuranukuran yang dipakai dalam pertumbuhan ekonomi sendiri belum bisa menjelaskan dan menyelesaikan masalah ketimpangan pendapatan dan pengangguran di Indonesia. Fenomena lemahnya peran serta masyarakat sekarang tidak hanya terjadi dibidang pembangunan tetapi sudah meluas ke berbagai bidang baik ekonomi, sosial, politik dan hukum serta pertahanan dan keamanan (Mu'man 2003; Syarif Ibrahim, 1999). Ini bisa dilihat dengan meningkatnya angka kemiskinan, kriminalitas, epidemi berbagai penyakit menular hingga maraknya konflik yang terjadi. Oleh karena itu saat ini adalah sebuah keharusan bagi pemerintah untuk menjadi lebih responsif terhadap kebutuhan masyarakat dan sektor publi $\mathrm{k}$ dengan modernisasi program yang dapat memberikan peluang untuk partisipasi warga. Sehingga masyarakat tidak lagi dilihat sebagai penerima program pembangunan melainkan ditempatkan sebagai pelaku atau subyek utama dalam pembangunan.

Paradigma baru yang berkembang lebih menekankan kepada proses-proses partisipatif dan kolaboratif yang ditujukan untuk meningkatkan kesejahteraan sosial dan material, termasuk meningkatnya keadilan dalam distribusi pemilikan, pengelolaan dan manfaat pembangunan serta kebebasan dan keterlibatan penduduk dalam proses pembangunan dapat pula diartikan bagaimana penduduk memanfaatkan program pembangunan yang telah diprogramkan oleh pemerintah, tetapi juga berarti bagaimana prakarsa dan kreativitas penduduk sendiri kemandirian (Rustiadi, Saefulhakim dan Panuju, 2011). Hal ini dimaksudkan agar pemerintah tidak lagi melakukan intervensi terlalu jauh dalam berbagai aspek kehidupan masyarakat. Korten (1986) menegaskan bahwa pembangunan masyarakat akan efektif apabila dilaksanakan dengan memanfaatkan organisasi masyarakat. Dan pemerintah berperan sebagai regulator, fasilitator dan motivator ada di tingkat lokal (Suradi, 2006).

Setelah reformasi banyak daerah yang mendapatkan hak Otonomi Daerah sebagai kelanjutan dari proses perubahan. Otonomi Daerah yang secara efektif mulai dilaksanakan pada tahun 2001 merupakan upaya untuk memangkas mata rantai proses pembangunan yang panjang dan sentralistik, sebagaimana diterapkan oleh pemerintahan sebelumnya. Otonomi Daerah untuk mendekatkan hubungan fungsional antara pemerintah daerah dengan masyarakat. Kebijakan otonomi daerah, pertama adalah UU No. 22 Tahun 1999 tentang Pemerintahan Daerah dan UU No. 25 Tahun 1999 tentang Perimbangan Keuangan antara Pusat dan Daerah. Dalam perjalanannya sesuai dengan kebutuhan demokrasi dan pembangunan daerah, UU No. 22 Tahun 1999 dan UU No. 25 Tahun 1999 telah dinilai baik dari segi kebijakan dan implementasinya, dan seiring kondisi zaman ternyata UU No. 22 Tahun 1999 dan UU NO. 25 Tahun 1999 mengalami kelemahan sehingga undang-undang tersebut mengalami revisi menjadi UU. 32 Tahun 2004 dan UU No. 33 Tahun 2004. Pada dasarnya semangat dan tujuan Undang-Undang Otonomi Daerah dan sesentralisasi, memberikan ruang (kewenangan) pemerintah daerah untuk merencanakan dan melaksanakan kebijakan dan program yang sesuai dengan potensi daerahnya masing-masing.

Demokratisasi diera otonomi daerah telah mendesain ulang pola-pola relasi pembangunan antara negara (pemerintah daerah) dan masyarakat ke arah yang lebih setara dan seimbang. Hubungan yang seimbang antara pemerintah dan masyarakat tidak hanya manifestasi dari pelaksanaan otonomi daerah, tetapi model hubungan yang demikian itu juga merupakan tuntutan kebutuhan masyarakat, sehingga memudahkan pencapaian kemajuan pembangunan daerah dan kesejahteraan masyarakatnya. Bertemunya antara akses pembangunan yang datang dari atas dan respon dari bawah merupakan inti dari partisipasi penduduk dalam proses pembangunan. Keterlibatan penduduk dalam 
proses pembangunan dapat menempatkan penduduk baik subyek maupun obyek pembangunan. Sebagai subyek pembangunan penduduk diharapkan ikut serta menentukan pilihan-pilihan pembangunan di daerahnya. Sedangkan sebagai obyek pembangunan, penduduk ditempatkan sebagai sasaran pembangunan (Rustiadi, Saefulhakim dan Panuju, 2011)

Di Sulawesi Utara khususnya di Kota Manado yang dahulunya merupakan kesatuan dari kabupaten Minahasa adalah salah satu contoh dari sistem pemerintahan Otonomi daerah yang ingin memekarkan diri dengan tujuan agar program pembangunan lebih tersentuh dan terfokus kepada masing-masing kelurahan. Kota Manado sejak masa kemerdekaan telah beberapa kali mengalami perubahan status dalam struktur pemerintahan. Semula masuk dalam kategori Kotapraja (19571958), Daerah Tingkat II (1958-1965), Kotamadya (1965-1974), Kotamadya Daerah Tingkat II (1974-1999), Kota Manado (1999 saat ini). Kota Manado dihuni oleh penduduk berjumlah 425.634 jiwa (data BPS Provinsi Sulawesi Utara tahun 2015). Bertambahnya jumlah penduduk setiap tahun dan peningkatan rasio pertumbuhan ekonomi memunculkan masalahan-masalah baru yang dampaknya dapat dilihat pada meningkatnya angka kemiskinan dan pengangguran. Begitu juga ketersediaan anggaran menyebabkan pemerataan pembangunan selama ini belum menjangkau seluruh wilayah di Kota Manado, sehingga memunculkan dikotomi UtaraSelatan akibat dari pembangunan sarana prasarana lebih banyak diserap wilayah daratan khususnya di bagian Selatan daripada wilayah kepulauan dan bagian Utara. Untuk menjawab tantangan permasalahan pembangunan prasarana dan sosial yang belum merata, khususnya di tingkatan pemerintahan yang terbawah yang seringkali tidak terjangkau pembangunannya melalui anggaran Pemerintah Kota Manado, membuat suatu terobosan baru sebagai acuan dalam upaya pembangunan infrastruktur dan sosial yang berbasis pada pemberadayaan masyarakat serta meningkatkan kapasitas masyarakat baik secara individu maupun kelompok dalam memecahkan berbagai pesoalan terkait upaya peningkatan kualitas hidup, kemandirian dan kesejahteraan masyarakat.

Dasar filosofi program ini adalah "Mapalus" yang dalam bahasa Minahasa memiliki arti semangat gotong royong. Program yang diberi nama dengan Program Pembangunan Berbasis Lingkungan Membangun Prasarana Lingkungan, Sosial dan Ekonomi (PBL-Mapalus), ini bertujuan selain untuk mempercepat dan meratakan pembangunan prasarana dasar permukiman juga sekaligus mengajak secara aktif masyarakat untuk terlibat secara langsung dalam kegiatankegiatan pembangunan prasarana dasar di lingkungannya. Melalui program ini diharapkan masyarakat akan merasa terpanggil untuk melaksanakan kegiatan pembangunan mulai tahap perencanaan proyek, tahap evaluasi sampai tahap pelaksanaannya.

Diawal pelaksanaannya Tahun 2012 program ini diberi nama Pembangunan Berbasis Lingkungan - Membangun Prasarana Lingkungan, Sosial dan Ekonomi (PBLMAPALUSE) di tahun berikutnya 2013 diubah menjadi Pembangunan Berbasis Lingkungan Membangun Prasarana Lingkungan dan Sosial (PBL-MAPALUS) dan hingga sekarang menggunakan nama PBL-MAPALUS. Sesuai kebijakan Pemerintah Kota Manado lokasi sasaran Pembangunan Berbasis Lingkungan Membangun Prasarana Lingkungan dan Sosial (PBL-MAPALUS) mencakup seluruh lingkungan di 87 Kelurahan yang ada di Kota Manado yaitu sebanyak 504 Lingkungan. Pembangunan Berbasis Lingkungan Membangun Prasarana Lingkungan dan Sosial (PBL-MAPALUS) berlandaskan pada Peraturan Walikota Manado Nomor 46 Tahun 2011 sebagaimana telah beberapa kali diubah terakhir dengan Peraturan Walikota Manado Nomor 12 Tahun 2015 Tentang Pembangunan Berbasis Lingkungan - Membangun Prasarana Lingkungan dan Sosial Di Kota Manado. Ruang lingkup kegiatan Pembangunan Berbasis Lingkungan - Membangun Prasarana Lingkungan dan Sosial (PBL-MAPALUS) terbagi 2 yang terdiri dari Kegiatan Pembangunan Prasarana Lingkungan dengan Infrastruktur sederhana dan pengadaan 
barang/peralatan serta kegiatan pembangunan sosial kemasyarakatan. Program ini pada hakekatnya Pemerintah Kota Manado memberikan anggaran stimulan terbatas untuk pembangunan prasarana dasar kepada warga masyarakatnya dilaksanakan secara mapalus disetiap lingkungan dalam wilayah kelurahan. Keterbatasan anggaran yang diterima oleh masyarakat tersebut diharapkan akan menimbulkan bentuk swadaya masyarakat untuk mewujudkan prasarana yang dinginkannya. Subtansi dasar dititikberatkan pada penumbuhan partisipasi nyata masyarakat dikelurahan untuk membangun lingkungan sekitar tempat pemukuman serta kepedulian dan solidaritas untuk bahu membahu menanggulangi permasalahan yang ada di lingkungan secara mandiri dan berkelanjutan. Pembangunan Berbasis Lingkungan - Membangun Prasarana Lingkungan dan Sosial (PBL-MAPALUS) sendiri mengunakan pendekatan Dari, Oleh dan Untuk Masyarakat (ODUM). Secara umum peran Pemerintah Kota Manado dalam kegiatan PBL-Mapalus adalah sebagai regulator, dinamisator, koordinator dan fasilitator.

\section{Rumusan Masalah}

Berdasarkan latar belakang yang telah diuraikan, maka yang menjadi permasalahan penelitian ini adalah untuk menganalisis bagaimana partisipasi masyarakat dalam meningkatkan kualitas prasarana infrastruktur melalui Program Pembangunan Berbasis Lingkungan - Membangun Prasarana Lingkungan dan Sosial (PBL-MAPALUS) di Kota Manado.

\section{Tujuan Penelitian}

Penelitian ini bertujuan untuk mengidentifikasi bentuk dan tingkat partisipasi masyarakat dalam tahap perencanaan, pelaksanaan, pengawasan Program Berbasis Lingkungan - Membangun Prasarana Lingkungan dan Sosial (PBL-Mapalus).

\section{Manfaat Penelitian}

Manfaat penelitian ini untuk pelaksanaan program pembangunan selanjutnya dan sebagai informasi tambahan bagi para pemerintah.

\section{METODOLOGI PENELITIAN}

\section{Lokasi dan Waktu Penelitan}

Penelitian ini dilaksanakan di Kecamatan Tuminting (wilayah pesisir dan berada di Wilayah Manado Utara) dan Kecamatan Wanea (wilayah perkotaan dan berada di Wilayah Manado Selatan) Kota Manado Propinsi Sulawesi Utara. Waktu pelaksanaan penelitian dari bulan Februari 2016 sampai dengan bulan Juni 2016.

\section{Jenis dan Sumber Data}

Jenis data yang digunakan di dalam melaksanakan penelitian ini yaitu data primer dan data sekunder. Data primer merupakan data yang didapat langsung di lapangan, melalui wawancara dan observasi dengan menggunakan daftar pertanyaan/kuesioner. Data sekunder merupakan data yang diperoleh dari instansi terkait seperti Badan Pemeberdayaan Masyarakat dan Pemerintahan Kelurahan Kota Manado, Kantor Lurah Bumi Nyiur dan Kantor Lurah Tuminting.

\section{Variabel Penelitian}

Dalam penelitian ini terdapat 5 (lima) variabel, yaitu:

1. Partisipasi masyarakat dalam bentuk sumbangan pikiran, masyarakat menyumbangkan ide atau gagasan dalam RKL (Rapat Kerja Lingkungan).

2. Partisipasi masyarakat dalam bentuk sumbangan tenaga, masyarakat secara sukarela turut serta dalam pembangunan fisik.

3. Partisipasi masyarakat dalam bentuk sumbangan keahlian, masyarakat rela untuk menyumbangkan kemampuan dan keterampilannya dalam pelaksanaan pembangunan fisik dan masyarakat rela untuk menyumbangkan kemampuan dan keterampilannya dalam pembuatan proposal.

4. Partisipasi masyarakat dalam bentuk sumbangan barang, masyarakat secara sukarela menyumbangkan peralatan dalam pelaksanaan pembangunan fisik dan masyarakat secara sukarela 
menyumbangkan bahan-bahan bangunan dalam pelaksanaan pembangunan fisik.

5. Partisipasi masyarakat dalam bentuk sumbangan uang, masyarakat secara swadaya menyumbangkan sejumlah uang dalam pelaksanaan pembangunan fisik.

\section{Metode Pengambilan Sampel}

Teknik pengambilan sampel atau teknik sampel yang akan digunakan dalam penelitian ini adalah Purposive Sampling. Metode ini dilakukan dengan mengambil orang-orang yang terpilih betul oleh peneliti menurut ciri-ciri spesifik yang dimiliki oleh sampel itu (Nasution, 2006:98).

\section{Metode Analisis Data}

Metode analisa data yang digunakan adalah analisis kuantitatif. Data penilitian yang diperoleh dianalisa dengan distribusi frekuensi.

\section{HASIL DAN PEMBAHASAN}

\section{DESKRIPSI WILAYAH PENELITIAN \\ 1. Keadaan Geografis \\ Berdasarkan PERDA Kota Manado} Nomor 2 Tahun 2012 Kota Manado dimekarkan kembali menjadi 11 kecamatan dengan 87 kelurahan. Kelurahan Bumi Nyiur termasuk dalam wilayah pemerintahan Kecamatan Wanea sedangkan Kelurahan Tuminting berada dalam wilayah pemerintahan Kecamatan Tuminting. Kelurahan Bumi Nyiur memiliki luas wilayah paling besar 88,20 Ha sedangkan Kelurahan Tuminting memiliki luas 43,83 Ha. Sebagai bagian dari wilayah administratif Pemerintah Kota Manado koordinat Letak geografis dan batas wilayah Kelurahan Tuminting dan Kelurahan Bumi Nyiur dapat dilihat pada tabel 1.

2. Jumlah Penduduk

Jumlah penduduk di tahun 2015 berdasarkan data Prodeskel Kelurahan Tuminting 6.629 jiwa sedangkan Kelurahan Bumi Nyiur memiliki jumlah penduduk 3.549 jiwa. Persentase jumlah penduduk menurut jenis kelamin di kedua Kelurahan ditunjukkan pada Tabel 2.

\section{HASIL PENELITIAN}

1. Karakteristik Responden

Hasil perhitungan frekuensi kondisi sosial ekonomi berdasarkan sampel di Kelurahan Bumi Nyiur dan Kelurahan Tuminting, lebih jelasnya dapat dilihat pada Tabel 3. Berdasarkan hasil kuesioner yang telah diedarkan kepada masyarakat tentang Partisipasi masyarakat Pada Program Pembangunan Berbasis Lingkungan Membangun Prasarana Lingkungan Dan Sosial (PBL-Mapalus), maka yang didapatkan jenis kelami laki-laki sebanyak 47 orang $(63 \%)$ pada Kelurahan Bumi Nyiur dan 41 orang $(55 \%)$ pada Kelurahan Tuminting. Untuk jenis kelamin perempuan sendiri 28 orang (37\%) untuk Kelurahan Bumi Nyiur dan 34 orang (45\%) untuk Kelurahan Tuminting.

Apabila dilihat dari tingkat pendidikan yang telah ditempuh oleh penduduk dikedua kelurahan obyek penelitian maka presentase terbanyak adalah berpendidikan setingkat SLTA. Di Kelurahan Bumi Nyiur jumlah responden yang telah menamatkan sampai ke jenjang setingkat SLTA adalah sebanyak 43 orang atau $57 \%$, Kelurahan Tuminting sebanyak 40 orang $(53 \%)$. Sementara pendidikan Akademi memiliki persentase paling kecil dimana sebanyak $8 \%$ untuk Kelurahan Bumi Nyiur dan $4 \%$ untuk Kelurahan Tuminting. Untuk lebih jelasnya mengenai frekuensi tingkat pendidikan dapat dilihat pada Tabel 4.

Berdasarkan pengamatan ini maka semakin tinggi tingkat pendidikan masyarakat maka akan semakin tinggi pula tipologi kelurahanya. Kita dapat melihat perbedaan yang disebabkan tingkat pendidikan dalam hal partisipasi masyarakat dalam melaksanakan program Pembangunan Berbasis Lingkungan Membangun Prasarana Lingkungan dan Sosial (PBL-Mapalus), dimana dengan tersedianya tenaga ahli dan terdidik sebagai inovator pembangunan semua proses mulai dari perencanaan, pelaksanaan, pengawasan serta pemeliharaan akan berjalan dengan baik.

2. Analisis Bentuk Partisipasi Masyarakat Pada Tahap Perencanaan. Hasil dari kuisioner yang diberikan kepada warga berkaitan dengan partisipasi masyarakat pada tahap perencanaan Program Pembangunan Berbasis Lingkungan - 
Membangun Prasarana Lingkungan Dan Sosial (PBL-Mapalus), $\quad 77 \%$ responden pada Kelurahan Bumu Nyiur ikut berpartisipasi sedangkan 23\% tidak ikut berpartisipasi. Untuk Kelurahan Tuminting responden yang ikut berpartisipasi $68 \%$ dan yang tidak berpartisipasi $32 \%$. Ada beberapa alasan responden tidak ikut berpartisipasi. Sebagian besar responden yang tidak ikut berpartisipasi dikarena mereka tidak mengetahui tentang Program Pembangunan Berbasis Lingkungan - Membangun Prasarana Lingkungan Dan Sosial (PBL-Mapalus) dapat dilihat pada Tabel 5. Tabel 5 menunjukan bahwa responden di Kelurahan Bumi Nyiur masih lebih tinggi persentasi partisipasi dalam tahap perencanaan ini dibandingkan dengan Kelurahan Tuminting. Slamet (1994) dalam Sutami (2009) mengatakan bahwa tingginya animo responden dalam berpartisipasi, agar warga mampu mengontrol keputusan-keputusan yang mempengaruhi nasib mereka.

3. Analisis Bentuk Partisipasi Masyarakat pada Tahap Pelaksanaan Pembangunan. Jawaban responden dengan pertanyaan apakah ikut berpartisipasi pada tahap pelaksanaan pembangunan pada Program Pembangunan Berbasis Lingkungan - Membangun Prasarana Lingkungan dan Sosial (PBL-Mapalus) sebanyak $83 \%$ responden Kelurahan Bumi Nyiur berpartisipasi sedangkan pada Kelurahan Tuminting hanya sebesar $73 \%$, selengkapnya dapat dilihat pada tabel 6. Bila dibandingkan dengan partisipasi masyarakat pada perencanaan pembangunan, maka pada tahap ini partisipasi masyarakat meningkat.

4. Analisis Bentuk-bentuk Partisipasi masyarakat pada tahap pelaksanaan pembangunan. Bentuk-bentuk partisipasi masyarakat pada pelaksanaan pembangunan dapat dilihat pada Tabel 7. Bentuk partisipasi yang diberikan cukup tinggi, ini dapat dilihat pada saat pelaksanaan Program Berbasis Lingkungan - Membangun Prasarana Lingkungan dan Sosial (PBL-MAPALUSE). Ini membuktikan bahwa manfaat dari dana stimulan yang diberikan membuat masyarakat termotivasi untuk turut serta membangun lingkungannya dalam berbagai bentuk partisipasi.

Tabel. 1 Koordinat Letak geografis dan Batas Wilayah

\begin{tabular}{|c|c|c|c|c|c|}
\hline Kelurahan & Koordinat Letak & \multicolumn{4}{|c|}{ Batas Wilayah } \\
\cline { 3 - 6 } & Geografis & Utara & Selatan & Timur & Barat \\
\hline Bumi Nyiur & $124.86952 \mathrm{LS} / \mathrm{LU}-$ & Kelurahan & Kelurahan & Kelurahan & Kelurahan \\
& $1.448796 \mathrm{BT} / \mathrm{BB}$ & Wanea & Pakowa & Wanea & Wanea \\
Tuminting & $124.861964 \mathrm{LS} / \mathrm{LU}-$ & Kelurahan & Kelurahan Bitung & Kelurahan & Kelurahan \\
& $1.527595 \mathrm{BT} / \mathrm{BB}$ & Mahawu & Karangria & Sumompo & Singkil Dua \\
\hline
\end{tabular}

Tabel. 2 Jumlah Penduduk

\begin{tabular}{|c|c|c|c|}
\hline \multirow{2}{*}{ Kelurahan } & \multicolumn{3}{|c|}{ Jumlah Penduduk } \\
\hline & Laki-laki & Perempuan & Total \\
\hline Tuminting & $3.285 \quad 36$ & 3.344 & 6.629 \\
\hline Bumi Nyiur & 1.769 & 1.780 & 3.549 \\
\hline
\end{tabular}

Tabel. 3 Frekuensi Jenis Kelamin

\begin{tabular}{|c|l|c|c|c|c|}
\hline \multirow{2}{*}{ No } & \multirow{2}{*}{ Jenis Kelamin } & \multicolumn{2}{|c|}{ Kelurahan Bumi Nyiur } & \multicolumn{2}{c|}{ Kelurahan Tuminting } \\
\cline { 3 - 6 } & & Responden & Persentase & Responden & Persentase \\
\hline 1 & Laki-Laki & 47 & 63 & 41 & 55 \\
\hline 2 & Perempuan & 28 & 37 & 34 & 45 \\
\hline \multicolumn{2}{|c|}{ JUMLAH } & 75 & 100 & 75 & 100 \\
\hline
\end{tabular}


Tabel. 4 Frekuensi Tingkat Pendidikan

\begin{tabular}{|l|l|c|c|c|c|}
\hline \multirow{2}{*}{ No } & \multirow{2}{*}{ Jenis Kelamin } & \multicolumn{2}{|c|}{ Kelurahan Bumi Nyiur } & \multicolumn{2}{c|}{ Kelurahan Tuminting } \\
\cline { 3 - 6 } & & Responden & Persentase & Responden & Persentase \\
\hline 1 & SD & - & - & - & - \\
\hline 2 & SLTP & 9 & 12 & 27 & 36 \\
\hline 3 & SLTA & 43 & 57 & 40 & 53 \\
\hline 4 & Akademi & 6 & 8 & 3 & 4 \\
\hline 5 & Perguruan Tinggi & 17 & 23 & 5 & 7 \\
\hline \multicolumn{2}{r}{ JUMLAH } & 75 & 100 & 75 & 100 \\
\hline
\end{tabular}

Tabel. 5 Partisipasi Masyarakat Pada Tahap Perencanaan

\begin{tabular}{|l|c|c|c|c|c|}
\hline \multirow{2}{*}{ No } & Partisipasi Masyarakat & \multicolumn{2}{|c|}{ Kelurahan Bumi Nyiur } & \multicolumn{2}{c|}{ Kelurahan Tuminting } \\
\cline { 3 - 6 } & & Responden & Persentase & Responden & Persentase \\
\hline 1 & Ikut berpartisipasi & 58 & 77 & 51 & 68 \\
\hline 2 & Tidak ikut berpartisipasi & 17 & 23 & 24 & 32 \\
\hline \multicolumn{2}{r}{ JUMLAH } & 75 & 100 & 75 & 100 \\
\hline
\end{tabular}

Tabel. 6 Partisipasi Masyarakat pada Pelaksanaan Pembangunan

\begin{tabular}{|c|c|c|c|c|c|}
\hline \multirow{2}{*}{ No } & Partisipasi Masyarakat & \multicolumn{2}{|c|}{ Kelurahan Bumi Nyiur } & \multicolumn{2}{c|}{ Kelurahan Tuminting } \\
\cline { 3 - 6 } & & Responden & Persentase & Responden & Persentase \\
\hline 1 & Ikut berpartisipasi & 63 & 83 & 55 & 73 \\
\hline 2 & Tidak ikut berpartisipasi & 13 & 17 & 20 & 27 \\
\hline & JUMLAH & 75 & 100 & 75 & 100 \\
\hline
\end{tabular}

Tabel. 7 Bentuk Partisipasi Masyarakat Pada Tahap Pelaksanaan

\begin{tabular}{|l|l|c|c|c|c|}
\hline \multirow{2}{*}{ No } & \multirow{2}{*}{ Partisipasi Masyarakat } & \multicolumn{2}{|c|}{ Kelurahan Bumi Nyiur } & \multicolumn{2}{c|}{ Kelurahan Tuminting } \\
\cline { 3 - 6 } & & Responden & Persentase & Responden & Persentase \\
\hline 1 & Tenaga & 25 & 33 & 29 & 39 \\
\hline 2 & Keahlian & 12 & 16 & 4 & 5 \\
\hline 3 & Peralatan & 9 & 12 & 15 & 20 \\
\hline 4 & Material & 16 & 22 & 7 & 9 \\
\hline 5 & Tidak Berpartisipasi & 13 & 17 & 20 & 27 \\
\hline \multicolumn{2}{r}{ JUMLAH } & 75 & 100 & 75 & 100 \\
\hline
\end{tabular}

\section{KESIMPULAN DAN SARAN}

\section{Kesimpulan}

Hasil penelitian dan kajian terhadap partisipasi masyarakat pada pembangunan melalui Program Berbasis Lingkungan Membangun Prasarana Lingkungan dan Sosial (PBL-MAPALUSE) di Kelurahan Bumi Nyiur dan Kelurahan Tuminting menunjukkan bahwa keaktifan masyarakat untuk berpartisipasi cukup besar, hal ini terlihat dari keikutsertaan masyarakat dan pemberian bentuk partisipasi yang semakin meningkat. Jika dilihat dari keikutsertaan responden pada setiap tahapan pembangunan menunjukkan bahwa responden sudah melakukan kerjasama yang baik dengan pemerintah sebagai penggagas adanya program Program Berbasis Lingkungan Membangun Prasarana Lingkungan dan Sosial (PBL-MAPALUSE). Indikasi adanya kerjasama ini, menunjukkan bahwa partisipasi masyarakat telah berada pada tingkat kemitraan (partnership). 


\section{Saran}

Bagi pemerintah, dalam hal ini diwakili oleh lurah, ketua KMM dan Instansi terkait diharapkan agar lebih giat lagi mensosialisasikan program Program Berbasis Lingkungan - Membangun Prasarana Lingkungan dan Sosial (PBL-MAPALUSE) agar tingkat partisipasi masyarakat lebih tinggi.

\section{DAFTAR PUSTAKA}

Hetifah Sj Sumarto. 2003. Inovasi, Partisipasi Dan Good Governance 20 Prakarsa Inovatif Dan Partisipatif Di Indonesia , ed. 1, Yayasan Obor Indonesia. Jakarta

Korten, David C. 1989. Pembangunan Berpusat Pada Rakyat. Yayasan Obor Indonesia. Jakarta

Nuryana, Mu'man. 2003. Pola rekonsiliasi masyarakat antar Etnis Di Daerah Konflik Di Indonesi. Balatbang Sosial. Jakarta

Peraturan Walikota Manado Nomor 12 Tahun 2015 Tentang Pembangunan Berbasis Lingkungan - Membangun Prasarana Lingkungan Dan Sosial Di Kota Manado
Perda Kota Manado No. 2 Tahun 2012 Tentang Pemekaran Wilayah

Rustiadi, Saefulhakim dan Panuju. 2011. Perencanaan dan Pengembangan Wilayah. Crestpent Press dan Yayasan Pustaka Obor Indonesia. Jakarta

Suradi. 2006. Jurnal penelilian dan Pengembangan Usaha Kesejahteraan Sosial. Vol. 11. Pusat penelitian dan pengembangan Kesejahteraan Sosial Departemen Sosial RI. Jakarta

Simon Bolivar Manalu. 2015. Konsep Otonomi Daerah, Good Governance, dan Reinventing Government dalam Pembangunan Daerah http://www.kompasiana.com/simonman alu/konsep-otonomi-daerah-goodgovernance-dan-reinventinggovernment-dalam-pembangunandaerah

UU No.22 Tahun 1999 Tentang Pemerintahan Daerah

UU No.25 Tahun 1999 Tentang Perimbangan Keuangan antara Pusat dan Daerah

UU No. 25 Tahun 2004 Tentang Sistem Perencanaan Pembangunan Nasional 